E N T R E V I S T A S

\title{
Ser conscientes de la importante tarea de formar al profesorado para el logro de una buena herencia educativa. Entrevista a Miguel Ángel Santos Guerra
} To be awarre of the importaint task to teachers education to achieve a good educational legacy. Interview to Miguel Ángel Santos Guerra

Ester Caparrós Martín ${ }^{1}$, Noelia Alcaraz Salarirche ${ }^{2}$

To cite this article: Caparrós, E. y Alcaraz, N. (2019). Ser conscientes de la importante tarea de formar al profesorado para el logro de una buena herencia educativa. Entrevista a Miguel Ángel Santos Guerra.

Márgenes, Revista de Educación de la Universidad de Málaga, o (0), 129-130

DOI: http://dx.doi.org/10.24310/mgnmar.voio.6640

\section{ORCID $\quad{ }^{1}$ Ester Caparrós Martín}

Departamento de Didáctica y Organización Escolar, Universidad de Málaga ester.caparros@uma.es

${ }^{2}$ Noelia Alcaraz Salarirche

Departamento de Didáctica y Organización Escolar, Universidad de Málaga noe@uma.es

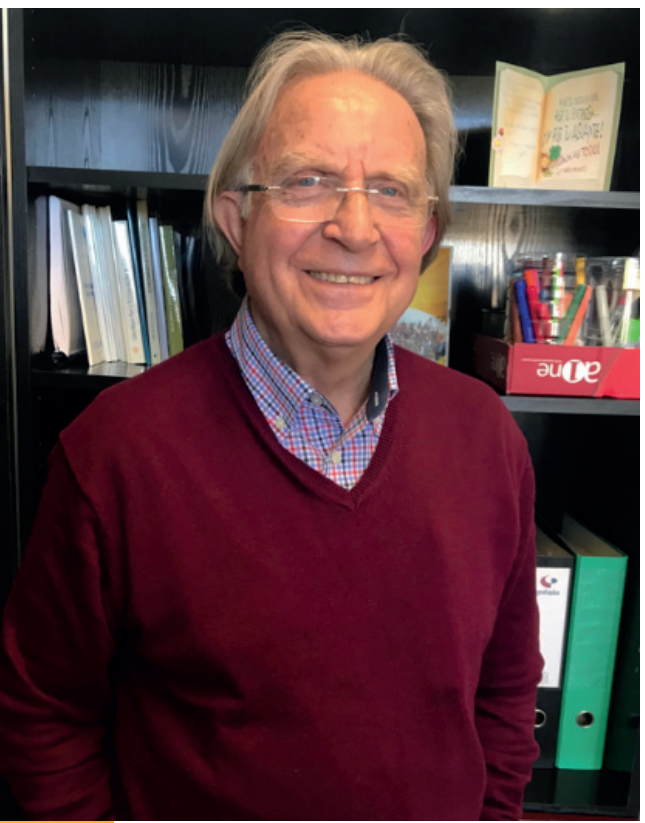

Palabras clave: formación del profesorado; organización educativa; pedagogía; conocimiento profesional

Keywords: teacher education; educational organization; pedagogy; professional knowledge

\section{BIOGRAFÍA}

Miguel Ángel Santos Guerra, ha sido profesor en la Facultad de Educación de la Universidad de Málaga hasta 2015. Es autor de numerosas obras de pedagogía, entre las que podemos destacar multitud de libros y artículos científicos sobre organización y dirección escolar, evaluación educativa y formación del profesorado. En la entrevista, el autor aborda varias cuestiones importantes a tener en cuenta en la formación del profesorado. Entre ellas, destacamos su preocupación acerca de quiénes son los que se dedican a formar las/ os futuras/os maestras/os en las Universidades y qué 
cualidades de la formación son las que priman en la actualidad; y un postulado, en el que pone de manifiesto la escasa conciencia que se tiene, desde las Facultades de educación, acerca de qué necesitan y cómo viven los maestras y maestros recién egresados el comienzo de su andadura en las escuelas. En definitiva, la labor de formación de docentes, según Santos Guerra, no debe circunscribirse a la mera adquisición de habilidades técnicas orientadas en exclusiva a "saber hacer" sino en el diseño, elaboración y planteamiento de un currículum que tenga en cuenta, fundamentalmente, el "saber ser".

\section{BIOGRAPHY OR ABSTRACT}

Miguel Ángel Santos Guerra has been a professor at the Faculty of Education of the University of Málaga until 2015 . He is the author of numerous works of pedagogy, among which we can highlight a multitude of books and scientific articles on school organization, school management, educational assessment and teacher education.

In the interview, the author raises several important issues to consider in teacher education; among them, we highlight their concern about who are those who are dedicated to train future teachers at universities and what qualities of training are those that prevail today; and a postulate, in which it manifests the scarce conscience we have, of the faculties of education, about what the graduated teachers need and how they live the beginning of their trip in the schools.

Definitely, the work of teacher training, according to Santos Guerra, should not be confined to the simple acquisition of technical skills "know how", but in the design, development and approach of a curriculum that takes into account, essentially, the "know how to be".

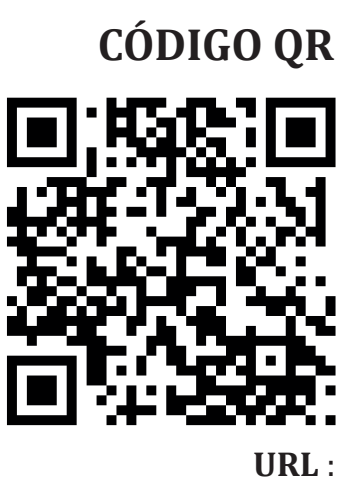

https://youtu.be/Q6WF10zEtpw 